Article

\title{
Environmental Assessment of a Coal Power Plant with Carbon Dioxide Capture System Based on the Activated Carbon Adsorption Process: A Case Study of the Czech Republic
}

\author{
Kristína Zakuciová ${ }^{1,2, *}$, Jiři Štefanica ${ }^{1}$, Ana Carvalho ${ }^{3}$ and Vladimír Kočí ${ }^{2, *}$ (i) \\ 1 ÚJV Řež, a. s., Hlavní 130, Řež, 25068 Husinec, Czech Republic; jiri.stefanica@ujv.cz \\ 2 Department of Environmental Chemistry, Faculty of Environmental Technology, \\ University of Chemistry and Technology, Prague, Technická 5, 16628 Praha 6, Czech Republic \\ 3 CEG-IST, Instituto Superior Técnico, Universidade de Lisboa, 1049-001 Lisbon, Portugal; \\ anacarvalho@tecnico.ulisboa.pt \\ * Correspondence: kristina.zakuciova@ujv.cz (K.Z.); vlad.koci@vscht.cz (V.K.); Tel.: +420-775-364 032(K.Z.)
}

Received: 3 April 2020; Accepted: 19 April 2020; Published: 4 May 2020

\begin{abstract}
The Czech Republic is introducing new technological concepts for mitigation of greenhouse gases (GHG) in coal-based energy industries. One such technology, in power plants, is post combustion $\mathrm{CO}_{2}$ capture from flue gases by activated carbon adsorption. A life cycle assessment (LCA) was used as the assessment tool to determine the environmental impacts of the chosen technology. This article focuses on a comparative LCA case study on the technology of temperature-swing adsorption of $\mathrm{CO}_{2}$ from power plant flue gases, designed for the conditions of the Czech Republic. The LCA study compares the following two alternatives: (1) a reference power unit and (2) a reference power unit with $\mathrm{CO}_{2}$ adsorption. The most significant changes are observed in the categories of climate change potential, terrestrial acidification, and particulate matter formation. The adsorption process shows rather low environmental impacts, however, the extended LCA approach shows an increase in energy demands for the process and fossil depletion as a result of coal-based national energy mix. The feasibility of the study is completed by the preliminary economical calculation of the payback period for a commercial carbon capture unit.
\end{abstract}

Keywords: carbon dioxide capture; activated carbon; environmental impacts; life cycle assessment

\section{Introduction}

In the Czech Republic, around $52.4 \%$ of the total gross electricity production (87.6 TWh) is generated from coal, which is approximately $41 \%$ of the energy mix [1]. The Czech industry emitted around 120.5 million tons $\mathrm{CO}_{2}$, with the largest proportion of 98 million tons in 2017 [2]. The major problem of reducing $\mathrm{CO}_{2}$ emissions and its sequestration lies with the implementation of carbon capture and storage (CCS) systems. It is commonly perceived that the implementation of CCS decreases local $\mathrm{CO}_{2}$ emissions and, if applied globally, supports mitigation efforts concerning the anthropogenic contribution to climate change. However, CCS technologies can be related to more complex, unexpected, or non-obvious environmental impacts. Thus, there is a common need for a holistic environmental approach that assesses and evaluates new industrial techniques and applications, which can significantly influence the environment. Results and conclusions based on such a holistic approach support the decision making of scientists, environmentalists, and governments concerning the implementation of new techniques and allow the environmental analysis in a wider and more detailed context. Life cycle assessment (LCA) is a tool for the assessment of technologies such as CCS, 
from both an environmental and sustainable point of view. A LCA uses different database methods and offers several approaches for the optimization of the processes and subsequent calculation of the environmental suitability of the chosen technology.

Considering several scientific references available (summarized in Table 1), there is a need for systematic environmental studies and reports that are built on local and site-specific operational data of the pilot $\mathrm{CO}_{2}$ capture plants. Most of the available studies deal with averaged environmental data from LCA databases and use hypothetical and mathematical models to describe a specific $\mathrm{CO}_{2}$ capture system. Current LCA studies focus on the comparison of several sorbents. Most studies specifically target post-combustion capture using monoethanolamine (MEA) sorbent. Comparative LCA analyses of MEA and potassium carbonate solvents have revealed that potassium carbonate solvents contribute to lower environmental impacts [3]. Compared to MEA, this process shows a reduction of emissions and energy cost savings. In [4], Manuilova compared power units with MEA sorbents and without $\mathrm{CO}_{2}$ capture and corroborated the general conclusions of other research works which reported a decrease in $\mathrm{SO}_{2}$ and particulate matter and an increase in NOx emissions due to MEA emissions. Additionally, increased levels of smog, water consumption, and water toxicity were also calculated. Koornneef [5] stated that $\mathrm{SO}_{2}$ and solid particle emissions decreased due to CCS implementation, but $\mathrm{NOx}, \mathrm{NH}_{3}$, and volatile organic compound emissions increased due to the utilization of amine and ammonia-based absorbents for $\mathrm{CO}_{2}$ capture. Petrakopoulou and Tsatsaronis [6] evaluated the environmental impacts of electricity generated by natural gas and coal power plants. The facts published by others $[5,7,8]$ also revealed that CCS required additional energy consumption, leading to a decrease in power plant efficiency and a greater potential of fossil fuel consumption. One recently studied technology using $\mathrm{CaCO}_{3}$ as the solvent, was the $\mathrm{CaO}$ looping system. A comparative LCA study by Clarens et al. [9] showed that $\mathrm{CaO}$ looping decreased $\mathrm{CO}_{2}$ emissions by 73 percent. A suitable alternative to the absorption processes based on amines can be adsorption separation of $\mathrm{CO}_{2}$. Under certain circumstances, adsorption can exceed $\mathrm{CO}_{2}$ absorption if the corrosive absorption medium is replaced by a solid sorbent, the absorption media treatment is removed, and the operational costs are decreased due to lower energy consumption during the regeneration step as compared with the regeneration of liquid solvents.

Regarding the activated carbon (AC) adsorption process, our literature survey revealed a study published by Hjaila et al. [10] about LCA of the production of AC from olive waste cakes. This study highlighted the most significant impacts of acidification and eutrophication due to the use of $\mathrm{H}_{3} \mathrm{PO}_{4}$ and the electricity demand for the AC production process. The software used in this study was SimaPro 7.3 based on the Ecoinvent database and the assessment method was CML 2 Baseline 2000. Another recent study associated with LCA and AC was conducted by Arena et al. [11]. This study evaluated the LCA of the production of AC from coconut shells. The life cycle inventory was based on the Ecoinvent 3.0 database, using CML-2001 as the LCA method and the software GaBi 6.0. The results demonstrated that global warming potential, acidification, and human toxicity represent the most significant environmental impacts. The environmental burdens are mainly associated with the production of electrical energy (based on hard coal) used in the production process of AC.

Currently, in the Czech Republic, CCS is in the stage of technical drafts and optimization of the systems, as well as economic assessment of the optimized solutions. These studies can be subsequently supported by the evaluation of environmental gains and impacts using the LCA approach. The environmental impacts have already been assessed for two technical solutions in the Czech Republic, i.e., a power plant with ammonia scrubbing of $\mathrm{CO}_{2}$ [12] and a power plant with high-temperature carbonate looping [13]. These processes face various operational issues that could be omitted by using low-temperature solid sorbents, such as zeolites or activated carbon. 
Table 1. Summary of life cycle assessment (LCA) studies on carbon capture and storage (CCS) technologies, including methods and results. PC, pulverized coal power plant; NGCC, natural gas combined cycle power plant; IGCC, integrated gasification combined cycle cycle power plant; SC-PC, subcritical pulverized coal; SPC-PC, supercritical pulverized coal; GWP, global warming potential; POP, photochemical oxidation potential; AP, acidifying potential; EP, eutrophication potential; PM10, PM-10 equivalents; ADP, abiotic depletion; ODP, ozone layer depletion; HTP, human toxicity; FAETP, freshwater aquatic ecotoxicity; MAETP, marine aquatic ecotoxicity; TET, terrestrial ecotoxicity.

\begin{tabular}{|c|c|c|c|}
\hline References & Scope & $\begin{array}{l}\text { LCA Software and } \\
\text { Database or Method }\end{array}$ & Significant LCA Impacts \\
\hline $\begin{array}{l}\text { Koornneef et al., } \\
2008\end{array}$ & $\begin{array}{c}\text { Comparative LCA study of SC-PC and SPC-PC } \\
\text { power plants with and without CCS } \\
\mathrm{CO}_{2} \text { capture by MEA absorption }\end{array}$ & $\begin{array}{c}\text { CML } 2 \text { baseline } 2000 \text { V2.03 } \\
\text { SW } \\
\text { EcoInvent database v1.3 }\end{array}$ & $\begin{array}{l}\text { ADP, GWP, ODP, HTP, FAETP, } \\
\text { MAETP, POP, AP, EP }\end{array}$ \\
\hline $\begin{array}{c}\text { Odeh and } \\
\text { Cockerill, } 2008\end{array}$ & $\begin{array}{l}\text { Comparative LCA study of SPC-PC, NGCC, } \\
\text { and IGCC power plants with and without CCS } \\
\mathrm{CO}_{2} \text { capture by MEA absorption }\end{array}$ & $\begin{array}{l}\text { SimaPro SW } \\
\text { EcoInvent }\end{array}$ & GWP \\
\hline Singh et al., 2012 & $\begin{array}{l}\text { Feasibility study of SC-PC and SPC-PC power } \\
\text { plants with and without } \mathrm{CO}_{2} \text { capture, FGD, } \\
\text { and SCR. } \\
\mathrm{CO}_{2} \text { capture by MEA absorption }\end{array}$ & EcoIndicator 99 & According to EcoIndicator 99 \\
\hline Hjaila et al., 2013 & $\begin{array}{l}\text { LCA of AC production from olive waste cakes } \\
\text { in Tunisia }\end{array}$ & $\begin{array}{c}\text { Simapro SW } \\
\text { CML } 2 \text { Baseline } 2000 \\
\text { Ecoinvent v } 2.2 \text { database }\end{array}$ & $\mathrm{AP}, \mathrm{EP}$ \\
\hline Grant et al., 2014 & $\begin{array}{l}\text { Comparative life cycle assessment of } \mathrm{K}_{2} \mathrm{CO}_{3} \\
\text { and MEA solvents for } \mathrm{CO}_{2} \text { capture from post } \\
\text { combustion flue gases }\end{array}$ & $\begin{array}{l}\text { CML } 2001 \text { methodology } \\
\text { Human and ecotoxicity } \\
\text { based on USETox method }\end{array}$ & $\begin{array}{l}\text { Potassium carbonate solvents } \\
\text { improves TET, carcinogen } \\
\text { emissions and energy } \\
\text { consumption }\end{array}$ \\
\hline $\begin{array}{l}\text { Manuilova et al., } \\
2014\end{array}$ & $\begin{array}{l}\text { Case study, Boundary Dam Power Station } \\
\mathrm{CO}_{2} \text { capture by MEA absorption }\end{array}$ & $\begin{array}{l}\text { Operational data by } \\
\text { Cenovus Energy, Canadian } \\
\text { provinces, USA and other } \\
\text { countries }\end{array}$ & $\begin{array}{l}\text { GWP, AP, EP, ODP, HTP, } \\
\text { FAETP }\end{array}$ \\
\hline $\begin{array}{l}\text { Petrakopoulou } \\
\text { and Tsatsaronis, } \\
2014\end{array}$ & $\begin{array}{c}\text { Comparative LCA study of PC and NGCC } \\
\text { power plants with and without CCS } \\
\mathrm{CO}_{2} \text { capture by MEA absorption and chemical } \\
\text { looping combustion }\end{array}$ & EcoIndicator 99 & According to EcoIndicator 99 \\
\hline $\begin{array}{l}\text { Clarens et al., } \\
2016\end{array}$ & $\mathrm{CaO}$ looping vs. MEA based adsorption & $\begin{array}{l}\text { ReCiPe Midpoint for Europe, } \\
\text { v } 1.04\end{array}$ & $\begin{array}{l}\text { Reductions in GWP category } \\
\text { for CaO looping }(73 \%), \\
\text { conventional MEA }(66 \%) \\
\text { advanced MEA }(72 \%)\end{array}$ \\
\hline Arena et al., 2016 & $\begin{array}{l}\text { LCA of activated carbon production from } \\
\text { coconut shells }\end{array}$ & $\begin{array}{l}\text { GaBi } 6.0 \text { software } \\
\text { CML-2001databank } \\
\text { Ecoinvent } 3.0\end{array}$ & HTP, AP, GWP \\
\hline
\end{tabular}

This study aims to analyze an integrated system of $\mathrm{Czech}$ brown coal power unit with $\mathrm{CO}_{2}$ capture based on an AC system, drafted and optimized as part of a national-scale project [14]. The main goal of this study is to identify key environmental impacts and the economic feasibility of the unit with integrated capture of $\mathrm{CO}_{2}$. The study intends to use operational data from pilot testing of the $\mathrm{CO}_{2}$ capture method based on adsorption to evaluate environmental impacts on the national conditions. In order to perform a holistic and systematic evaluation, the LCA study was performed in different levels of decision-making processes such as characterization, normalization, Pareto analysis, and input-output analysis. This study was completed by the economical evaluation of such CCU (carbon capture and utilization) unit. In summary, the main contributions of the paper are:

- An extensive literature survey of current LCA studies on various carbon capture technologies;

- Performance of a holistic environmental LCA case study on the unique technology of activated carbon adsorption of $\mathrm{CO}_{2}$ in Czech energy conditions;

- An LCA case study based on operational data of an operating 250 MW power unit from a national-scale project;

- Performance of robust LCA analyses for the adsorption capture process conducted at four decision making levels (characterization, normalization, Pareto analysis, and input-output analysis);

- An economical calculation of commercial CCU unit with payback period; 
- The identification of areas within a carbon capture technological process that can be improved to enhance environmental and economic performance.

The structure of this paper is comprised of the definition of a life cycle approach according to related international standards; the definition of the case study, i.e., description of Czech power unit and adsorption technology; implementation of the LCA methodology for the case study; characterization and interpretation of the environmental results; and finally, an economic evaluation of the case study.

\section{Methods}

\subsection{Environmental Assessment: The Life Cycle Assessment Method}

LCA is a tool to evaluate the environmental impacts of products and processes, such as the production of electricity. The LCA method is certified and defined by international standards ISO 14040 [15] as a cradle-to-grave analysis which facilitates a comparison of technological processes regarding their environmental characteristics. This includes all phases of a product's lifetime. According to the international standards, LCA consists of four steps, i.e., goal and scope definition, inventory analysis, impact assessment, and interpretation which are described as follows:

Step 1 Goal and scope definition

The depth of the analysis is determined by the goal of LCA. This study aimed to create a model and analyze the potential environmental impacts of $\mathrm{CO}_{2}$ adsorption on activated carbon connected to a 250 MW brown coal power unit. Therefore, two scenarios were considered:

1. Scenario 1 which is the assessment of electricity production by the $250 \mathrm{MW}$ coal power unit.

2. Scenario 2 which is the assessment of the electricity production by the $250 \mathrm{MW}$ coal power unit integrated with the $\mathrm{CO}_{2}$ adsorption unit.

For the comparison of the LCA results, a compatible functional unit must be defined for each scenario. The functional unit for both scenarios was defined as the power capacity ( $250 \mathrm{MW})$ of the power unit. System boundaries included the operational part of the power plant and activated carbon production, emission treatment, $\mathrm{CO}_{2}$ capture process, and waste generation. System boundaries excluded $\mathrm{CO}_{2}$ compression, transport, and final storage due to limited information about $\mathrm{CO}_{2}$ storage in the Czech conditions. Moreover, the environmental assessment included the operational part of the power plant rather than the life cycle of the $\mathrm{CO}_{2}$. Therefore, the approach used was considered to be "cradle-to-gate."

Step 2 Life cycle inventory (LCI)

LCI starts with data collection and model construction, in compliance with the goal and scope definition, followed by the collection of input-output data and calculation of the resource depletion and emission release during the production process. Operational data for the case study was collected from the pilot project report [14] with detailed technical requirements and descriptions.

Step 3 Life cycle impact assessment (LCIA)

LCIA can be divided into three steps, i.e., characterization, classification, and normalization. For the characterization and classification steps, the impact potentials were calculated. Normalization is an optional step of LCIA. Normalization uses a common reference impact to express results after the characterization and supports the comparison between alternative scenarios by using reference numerical scores. Normalization also gives a basis for comparing different types of impact categories [16]. The additional approach of Pareto analysis was chosen for defining the most significant impact categories. The selected method for the LCA analyses of the study was the ReCiPe 1.08 method. This method combines the problem-oriented approach of the CML method and the damage-oriented approach of EcoIndicator 99. The ReCiPe method is characterized by the following 18 midpoint indicators: ozone depletion (OD), human toxicity (HT), ionizing radiation (IR), photochemical oxidant formation (POF), particulate matter formation (PMF), terrestrial acidification (TA), climate change (CC), terrestrial ecotoxicity (TET), agricultural land occupation (ALO), urban land occupation (ULO), 
natural land transformation (NLT), marine ecotoxicity (MET), marine eutrophication (ME), fresh water eutrophication (FE), fresh water ecotoxicity (FET), fossil depletion (FD), metal depletion (MD), and water depletion(WD); in addition, there are three endpoint indicators, i.e., human health, ecosystems, and resource surplus costs $[17,18]$.

Step 4 Characterization and interpretation

This step is based on the results of the LCIA phase. The results are defined as a potential environmental impact. The environmental impact is calculated using characterization methods that associate the scale of a pollutant emission to selected characterization factors. The interpretation of the results includes an identification of significant issues, evaluation of completeness, and sensitivity of results. The interpretation phase also includes key conclusions and recommendations [19]. Normalized results are further assessed by the statistical method of Pareto's rule ( $80 / 20$ rule), which states that 20 percent from all impact categories cause 80 percent of the total environmental impacts [20,21].

In our case study LCA, for the Pareto analysis, we chose values after normalization for each impact category.

In summary, the full LCA analysis was performed for both scenarios applying the ReCiPe method. Then, the characterization and normalization (according to ReCiPe 1.08, midpoint normalization of the Europe region) steps were performed to interpret the environmental impacts of the chosen scenarios. Additional Pareto analyses with more detailed input-output analyses of the specific processes were performed to identify the most significant processes which influence relevant environmental impacts.

\subsection{Economical Assessment and Economical Inventory of the Carbon Capture Unit (CCU)}

The economical evaluation of the CCU can have a significant impact on the actual feasibility of the project and contributes to the sustainability assessment of the technology. The calculation predicts the cost for the construction of a newly built commercial CCU and payback period. The economical inventory of the required construction materials was estimated based on previous projects made for the Czech market by the experts of the biggest Czech energetic research group (ÚJV Řež, a. s.). The evaluation was part of a national scale project [14] for the CCU application and connection to the 250 MW power unit.

\section{Case Study Definition: Reduction of $\mathrm{CO}_{2}$ Emissions in the Czech Republic}

To understand and define the technological boundaries for comparing the systems, it is important to describe both scenarios from a technical point of view. Scenario 1 defines the basic systems of the reference power plant. Scenario 2 is described by the reference power unit with the adsorption process of $\mathrm{CO}_{2}$ capture systems.

\subsection{Scenario 1: Reference Power Plant}

The first scenario considers the concept of the reference case scenario of the real Czech power plant. Mass and energy flows for further LCA analysis are related to the power plant's operation, which consists of three independent power blocks, each with an installed power of $250 \mathrm{MW}$. Each power block includes a dry bottom boiler, a turbine and its auxiliaries, a generator, a fly-ash separator, a cooling tower, a transformer, and a desulphurization unit. Coal feeding, water management (pipeline, pump, and chemical treatment), stack, auxiliaries for fly-ash handling, and desulphurization are shared systems. Since 1996, several equipment modernizations have been added in the power plant, such as a desulphurization system based on wet-limestone scrubbing. The gypsum, a product of desulphurization, is deposited into an adjusted mining dump site. Moreover, a hydraulic ash removal system has been replaced by deposition of a mixture of ash, gypsum, and wastewater into an adjusted mining dump site. The modernization includes the research and development of suitable $\mathrm{CO}_{2}$ sorbents for specific conditions. One of the most viable and commercially affordable options seems to be capture by activated carbon [22]. 


\subsection{Scenario 2: Activated Carbon Adsorption for Reference Power Plant}

The second scenario considers the same reference power plant with the connected $\mathrm{CO}_{2}$ adsorption unit. Mass and energy flows for the next LCA analysis include the operational phase of the power plant and the adsorption unit [23]. For the Czech power plant, the pilot adsorption facility was designed by the UJV Rez group and it was a pilot project [14] for the adsorption of operational flue gases of the power unit. The adsorption unit is based on a rotative adsorber (Figure 1). The main advantages are the continuous operation of adsorption, easy regulation of the adsorption process, and being a viable source of activated coal. The pilot facility for $\mathrm{CO}_{2}$ separation from flue gases by the adsorption was designed for continuous operation in the conditions of real flue gases from the lignite power unit. The concept is based on the rotational adsorption part, where the main functional part is the fixed adsorption bed connected to the motor driven rotor. The adsorption wheel rotates at a predetermined velocity around its own axis and the speed determines the time of the whole adsorption-desorption cycle. The $\mathrm{CO}_{2}$ separation follows the desulphurization process, where flue gases are purified and cooled by $\mathrm{NaOH}$, and then the oxides $\mathrm{SOx}$ and $\mathrm{NOx}$ are removed. Cooled and purified flue gases pass through ventilators and through heating to the rotational adsorber for $\mathrm{CO}_{2}$ adsorption. Purified flue gases without $\mathrm{CO}_{2}$ are led out of the separation technology to the chimney or cooling tower. In the section of desorption, adsorbed $\mathrm{CO}_{2}$ is thermally displaced from the carbon sorbent by circulating gas heated by external steam. $\mathrm{CO}_{2}$ is continually transported for potential compression with $95 \%$ purity. The next step is the cooling of the sorbent to the requested temperature for adsorption. The whole process operates continuously by the rotation of the wheel. The pilot case rotative adsorber is pictured in Figure 1 [24]. The primary source of the activated carbon in Czech conditions is assumed to be hard coal from the ČSM mine site (Karvina region) with an annual mining of six million tons of hard coal [2]. The activation of the hard coal is based on two main steps, i.e., carbonization of the raw material in the absence of oxygen and activation of the carbonized product with water vapor. The heat supply necessary for the activation is obtained by combustion of gases produced during activation.

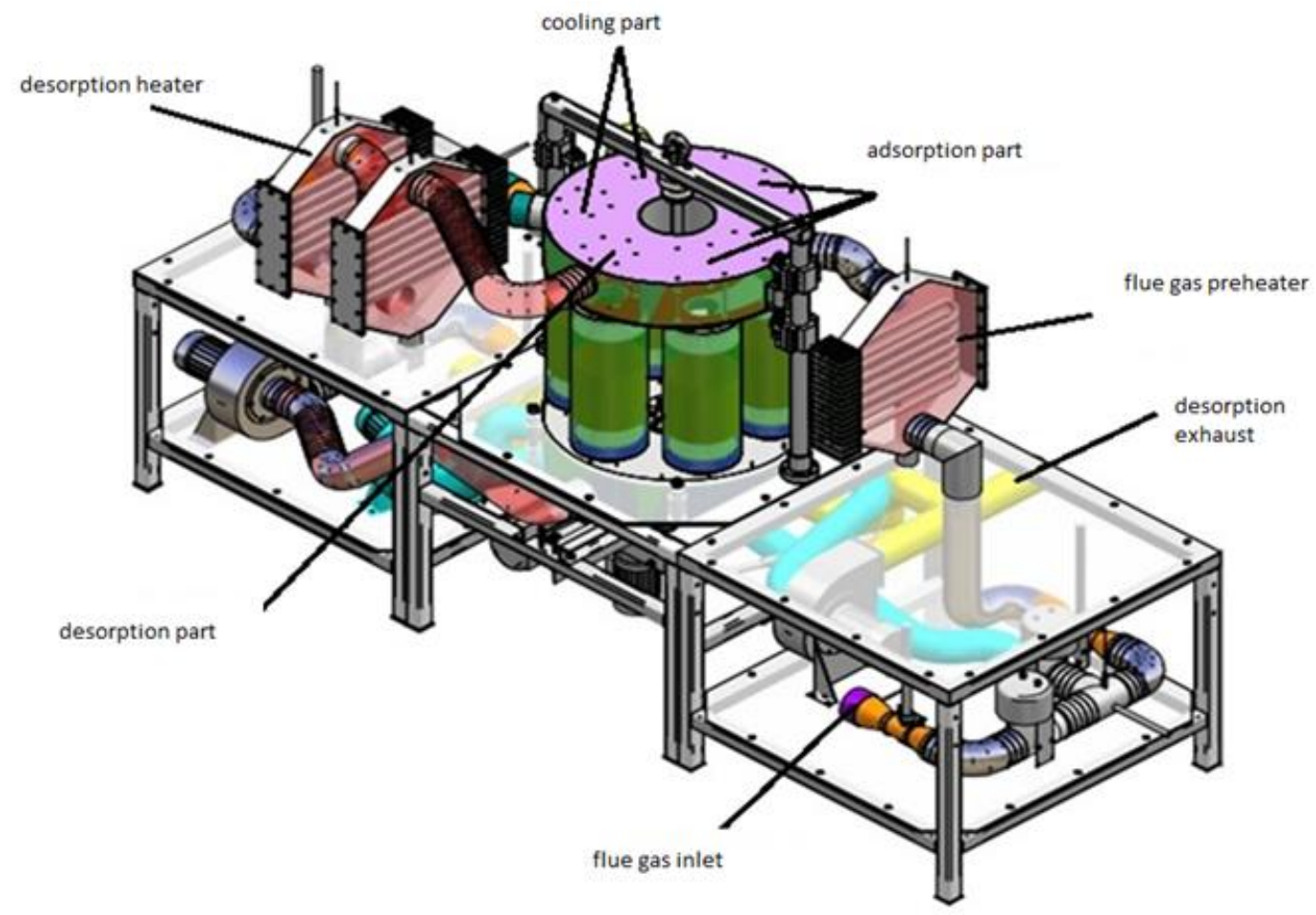

Figure 1. Case rotative adsorber. 


\subsection{LCA Study: System Boundaries Definition}

As stated previously, this study aims to identify the environmental impacts of a power plant with a carbon capture system integration using the designed adsorption method and comparing those impacts with a reference power plant without an adsorption system. The study also focuses on assigning the environmental impacts to the designed $\mathrm{CO}_{2}$ capture technology itself. The system boundary for Scenario 1 (Figure 2) includes a brown coal production chain from the mining process, transport of fuel to the power unit with power production, combustion, and flue gas treatment processes. Scenario 1 also includes waste and gas emissions production (residuals of flue gas after treatment as nitrogen oxides, carbon dioxide, and sulphur dioxide, released through a stack into the air). Scenario 2(Figure 3) includes a brown coal production chain, power unit operation with power and waste production, adsorption process with all relevant inputs, such as activated carbon production and production of $40 \% \mathrm{NaOH}$, and finally, output flows from the adsorption process (captured $\mathrm{CO}_{2}$, gas emissions and waste products). Although the CCS chain also includes transport and storage of captured $\mathrm{CO}_{2}$, our specific study does not include any operational data for transport and storage of $\mathrm{CO}_{2}$, as there is no specific solution of $\mathrm{CO}_{2}$ transport and storage in the Czech Republic and the distance from an emission source to a storage site with adequate storage capacity and lifetime is unique for every case.

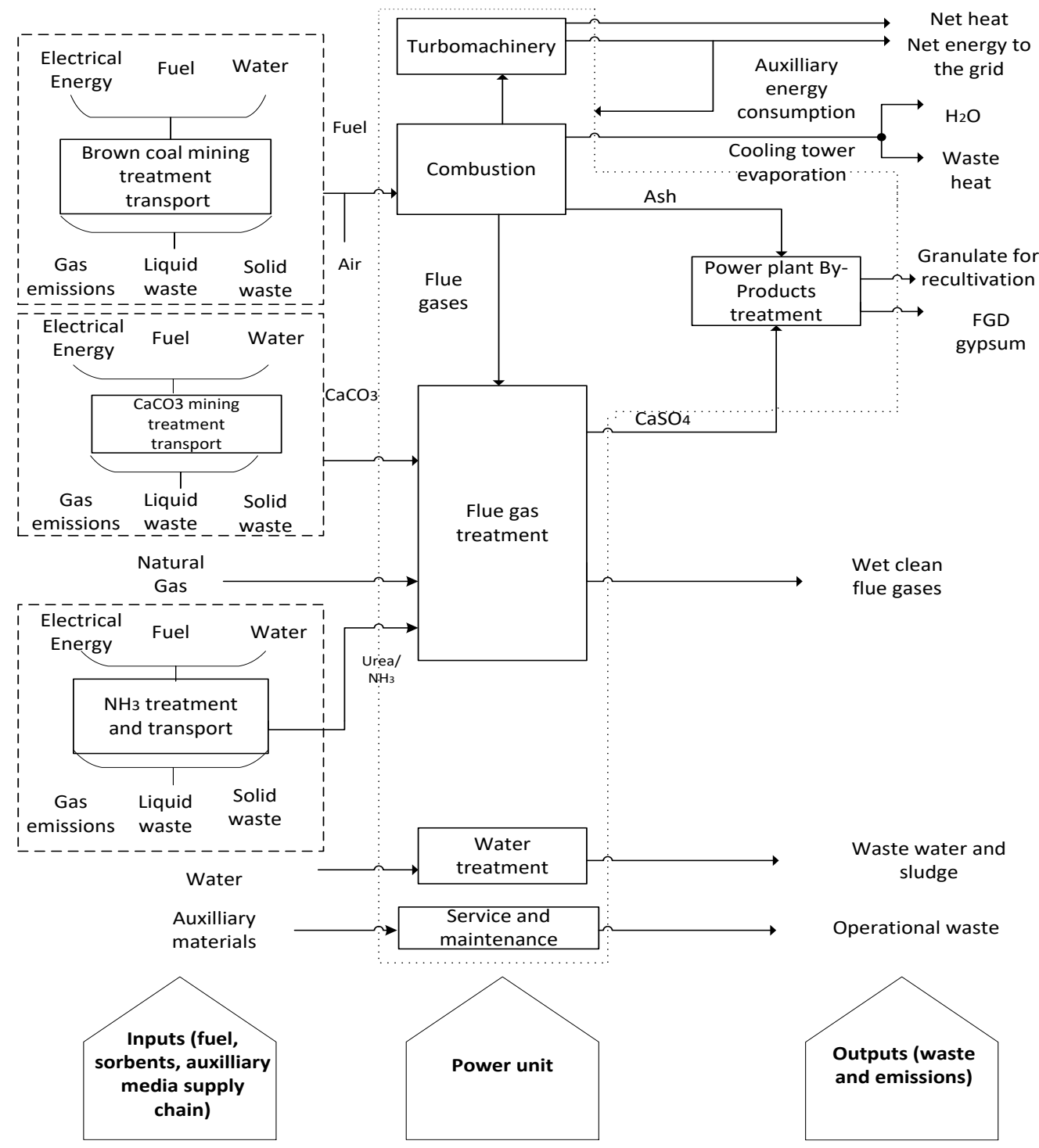

Figure 2. System boundaries for Scenario 1. 


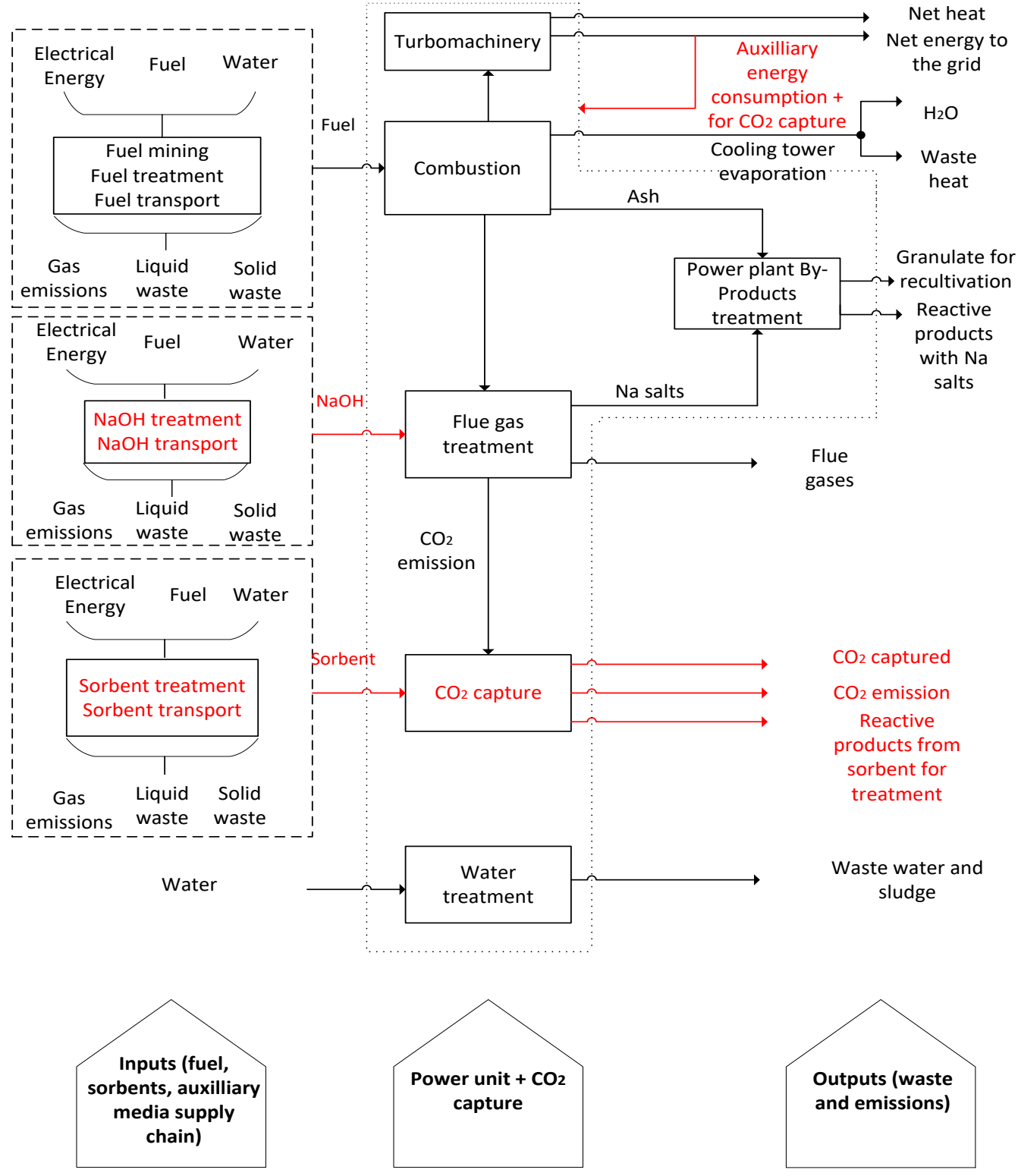

Figure 3. System boundaries for Scenario 2 (differences from Scenario 1 are marked in red).

\subsection{Life Cycle Inventory}

The input data for the power unit was based on the real power plant operational parameters. Its characteristics are given in Table 2. The heat and mass balances for $\mathrm{CO}_{2}$ capture technology (Table 3) were evaluated in relation to the power plant characteristics [14] and the results obtained from the pilot testing of the adsorption method.

Table 2. Characteristics of power unit without $\mathrm{CO}_{2}$ capture.

\begin{tabular}{ccc}
\hline Parameter & Value & Unit \\
\hline Nominal power output & 250 & $\mathrm{MW}$ \\
Brown coal production & 214 & $\mathrm{t} / \mathrm{h}$ \\
Yearly operation & 6300 & $\mathrm{~h}$ \\
Electricity produced & 1424 & $\mathrm{MWh} / \mathrm{y}$ \\
Wet flue gases & 766,045 & $\mathrm{~m}^{3} / \mathrm{h}$ \\
\hline
\end{tabular}


Table 3. Input data for the $\mathrm{CO}_{2}$ adsorption process.

\begin{tabular}{ccc}
\hline Parameter & Value & Unit \\
\hline Consumption of fresh activated & 23 & $\mathrm{~kg} / \mathrm{h}$ \\
carbon & 211 & $\mathrm{t} / \mathrm{h}$ \\
$\mathrm{CO}_{2}$ & 159 & $\mathrm{~kg} / \mathrm{h}$ \\
$\mathrm{NO}_{\mathrm{x}}$ & 119 & $\mathrm{~kg} / \mathrm{h}$ \\
$\mathrm{SO}_{2}$ & 222 & $\mathrm{MWt}$ \\
Waste heat & 23.08 & $\mathrm{MW}$ \\
Total energy consumption for $\mathrm{CO}_{2}$ & 9259 & $\mathrm{t} / \mathrm{h}$ \\
capture & 0.305 & $\mathrm{t} / \mathrm{h}$ \\
\hline Consumption of cooling water & &
\end{tabular}

In addition to the process of adsorption, the process of activation and carbonization of hard coal is also required to be included in the model. The input data was calculated for the initial batch of $7.6 \mathrm{t}$ of hard coal and $76 \mathrm{t}$ of tar (then activated and transformed into activated carbon). The energy consumption for the hard coal activation was calculated as $1133 \mathrm{MJ}$. Before the introduction of the flue gas from coal combustion into the $\mathrm{CO}_{2}$ adsorption stage, it must be secondary treated to decrease the amount of acid gases. To do so, flue gas after coal combustion is washed with a $\mathrm{NaOH}$ solution. The composition of the reacted products (output flows) after the reaction with $\mathrm{NaOH}$ is described in Table 4.

Table 4. Composition of products after the reaction between flue gas compounds and $\mathrm{NaOH}$.

\begin{tabular}{ccc}
\hline Compound & Value & Unit \\
\hline $\mathrm{Na}_{2} \mathrm{SO}_{3}$ & 235 & $\mathrm{~kg} / \mathrm{h}$ \\
$\mathrm{Na}_{2} \mathrm{SO}_{4}$ & 16.9 & $\mathrm{~kg} / \mathrm{h}$ \\
$\mathrm{NaCl}$ & 2.54 & $\mathrm{~kg} / \mathrm{h}$ \\
$\mathrm{NaF}$ & 6.67 & $\mathrm{~kg} / \mathrm{h}$ \\
$\mathrm{NaNO}_{2}$ & 119 & $\mathrm{~kg} / \mathrm{h}$ \\
$\mathrm{NaNO}_{3}$ & 147 & $\mathrm{~kg} / \mathrm{h}$ \\
\hline
\end{tabular}

The emission gases released into the air after the $\mathrm{CO}_{2}$ adsorption stage, the amount of wastewater, and of captured $\mathrm{CO}_{2}$ are depicted in Table 5 .

Table 5. Output data from the $\mathrm{CO}_{2}$ adsorption process.

\begin{tabular}{ccc}
\hline Parameter & Value & Unit \\
\hline $\mathrm{SO}_{2}$ & 68.6 & $\mathrm{~kg} / \mathrm{h}$ \\
$\mathrm{NOx}$ & 13.72 & $\mathrm{~kg} / \mathrm{h}$ \\
$\mathrm{CO}_{2}$ exhaust gas & 18.3 & $\mathrm{t} / \mathrm{h}$ \\
Captured CO $_{2}$ & 158 & $\mathrm{t} / \mathrm{h}$ \\
Wastewater & 19.73 & $\mathrm{t} / \mathrm{h}$ \\
\hline
\end{tabular}

Moreover, other conditions and assumptions in the LCA model were taken into consideration with respect to the technical concept of $\mathrm{CO}_{2}$ adsorption technology and its energy and mass balances as follows:

- The energy required for the $250 \mathrm{MW}$ power unit is determined by brown coal mix production in the conditions of the Czech Republic.

- The reactive product from the $\mathrm{NaOH}$ reaction is a non-utilized waste which would be stored at a landfill.

- The wastewater is processed in a wastewater treatment plant and the data for the wastewater treatment plant was taken from the general EU standard dataset thinkstep. 
- The primary resource of the activated carbon is hard coal, which is transported by diesel train for an average distance of $1000 \mathrm{~km}$.

- The energy source required for activated carbon activation and carbonization is natural gas.

\subsection{Economical Calculation}

For the calculation of the $\mathrm{CO}_{2}$ capture unit construction and connection to the average power plant, the following parameters were assumed:

- Capture effectivity 50\%;

- CCU unit would process $0.1 \%$ to $0.2 \%$ of flue gases produced by an average power plant block;

- $\quad \mathrm{CCU}$ unit would capture around $1200 \mathrm{tCO}_{2} /$ year.

The cost estimation of the construction of CCU is calculated according to the price of the required appliances. Then, the capital expenditure (CapEXP) is multiplied by the coefficient 1.7 (conservative estimate), which refers to the assumption that the construction is built as a fully new technology, and therefore some unexpected expenses could arise.

The operational costs (OpCost) for each item are difficult to estimate. Therefore, $5 \%$ of the capital expenditures were used as the operational cost value per year.

Incomes (In) are calculated from the cost of saved $\mathrm{CO}_{2}$ allowance for each ton of $\mathrm{CO}_{2}$ and the current market price of $\mathrm{CO}_{2}$. The authors used a more pessimistic scenario according to the EU commission reference for $\mathrm{CO}_{2}$ allowance of 25 Euro/t $\mathrm{CO}_{2}$ and the actual market price which is estimated to be 120 Euro/t $\mathrm{CO}_{2}$. Then, the payback period (PBT, simple, not discounted) for the commercial $\mathrm{CO}_{2}$ capture unit is calculated as following:

$$
\begin{gathered}
\text { In }=\mathrm{CO}_{2} \text { captured } *\left(\operatorname{CostCO}_{2} \text { allowance }+\operatorname{CostCO}_{2} \text { market }\right) \\
\text { PBT }=\frac{\text { CapEXP }}{(\text { In }- \text { OpCost })}
\end{gathered}
$$

\section{Results}

\subsection{Life Cycle Impact Assessment}

Steps 3 and 4 of LCIA are involved in the Results section. First, each scenario is analyzed separately, and then compared to each other. The results of both considered scenarios are represented in Table 6 . Table 6 summarizes the environmental impact categories into the following three groups of results: values in category units, normalization results without any units, and the relative contribution of each impact category to the sum of all categories. The relative contributions are computed from the normalization values.

According to the results, the relative contribution to the sum of impacts in Scenario 1 shows the highest contribution of $46.81 \%$ by fossil depletion and in $29.27 \%$ by climate change potential. In addition, almost $10 \%$ of the environmental impact contribution refers to the terrestrial acidification potential. For Scenario 1, the highest contribution of $77.41 \%$ is shown by fossil depletion. All other potential environmental impacts refer to much smaller contributions. For the comparison of both scenarios among the environmental impact categories, the normalization level of the decision-making process was considered. Further Pareto analysis describes the difference between values among the scenarios. 
Table 6. LCA results for both scenarios.

\begin{tabular}{|c|c|c|c|c|c|c|}
\hline & & Scenario 1 & & & Scenario 2 & \\
\hline $\begin{array}{c}\text { Environmental Impact } \\
\text { Categories }\end{array}$ & $\begin{array}{l}\text { Values in } \\
\text { Category } \\
\text { Units }\end{array}$ & $\begin{array}{c}\text { ReCiPe 1.08, } \\
\text { Mid-point } \\
\text { Normalization, } \\
\text { Europe, excl } \\
\text { biogenic carbon }\end{array}$ & $\begin{array}{c}\text { Relative } \\
\text { Contribution } \\
\text { in } \%\end{array}$ & $\begin{array}{c}\text { Values in } \\
\text { Category } \\
\text { Units }\end{array}$ & $\begin{array}{c}\text { ReCiPe 1.08, } \\
\text { Mid-point } \\
\text { Normalization, } \\
\text { Europe, excl } \\
\text { biogenic carbon }\end{array}$ & $\begin{array}{c}\text { Relative } \\
\text { Contribution } \\
\text { in } \%\end{array}$ \\
\hline $\operatorname{ALO}\left(m^{2} a\right)$ & 473 & 0.11 & 0.16 & 473 & 0.11 & 0.26 \\
\hline $\begin{array}{l}\text { CC, excl biogenic carbon }(\mathrm{kg} \\
\left.\mathrm{CO}_{2} \text { eq. }\right)\end{array}$ & 221,000 & 19.70 & 29.27 & 28,000 & 2.50 & 6.14 \\
\hline FD (kg oil eq.) & 49,100 & 31.50 & 46.81 & 49,100 & 31.50 & 77.41 \\
\hline FET (kg 1,4-DB eq.) & 1.24 & 0.11 & 0.17 & 1.25 & 0.12 & 0.28 \\
\hline FE (kg P eq.) & 0.023 & 0.05 & 0.08 & 0.02 & 0.05 & 0.13 \\
\hline HT (kg 1,4-DB eq.) & 171 & 0.29 & 0.43 & 171 & 0.29 & 0.71 \\
\hline IR (U235 eq.) & 314 & 0.05 & 0.07 & 314 & 0.05 & 0.12 \\
\hline MET (kg 1,4-DB eq.) & 1.46 & 0.17 & 0.26 & 1.46 & 0.17 & 0.42 \\
\hline ME (kg N eq.) & 7.83 & 0.78 & $\mathrm{I} .15$ & 2.18 & 0.22 & 0.53 \\
\hline MD (kg Fe eq.) & 16.20 & 0.02 & 0.03 & 16.20 & 0.02 & 0.06 \\
\hline $\operatorname{NLT}\left(\mathrm{m}^{2}\right)$ & 0.014 & 0.09 & 0.13 & 0.01 & 0.09 & 0.21 \\
\hline PMF (kg PM10 eq.) & 64.70 & 4.34 & 6.45 & 25.40 & 1.71 & 4.20 \\
\hline POF (kg NMVOC eq.) & 184 & 3.47 & 5.16 & 36.30 & 0.68 & 1.68 \\
\hline $\mathrm{TA}$ (kg SO 2 eq.) & 227 & 6.61 & 9.82 & 109 & 3.18 & 7.81 \\
\hline TET (kg 1,4-DB eq.) & 0.075 & 0.01 & 0.01 & 0.07 & 0.01 & 0.02 \\
\hline $\operatorname{ULO}\left(\mathrm{m}^{2} \mathrm{a}\right)$ & 0.016 & 0.00 & 0.00 & 0.02 & 0.00 & 0.00 \\
\hline $\mathrm{WD}\left(\mathrm{m}^{3}\right)$ & 6390 & 0.00 & 0.00 & 6400 & 0.00 & 0.00 \\
\hline Sum & - & 67.30 & 100 & - & 40.69 & 100 \\
\hline
\end{tabular}

\subsection{Pareto Analysis of the Scenarios and Processes}

The Pareto analysis defines $20 \%$ of the potential environmental impact categories that contribute to $80 \%$ of the total impact. The environmental impacts were divided into the following two groups of flows: (1) input flows which use, consume, or transform primary soil, land, or resources (agriculture land occupation, natural land transformation, and fossil depletion) and (2) output flows which are considered to be emissions from the considered processes. In the case of the input flows, for both scenarios, all the mentioned environmental categories have equal values and the highest among them has fossil depletion.

Figures 4 and 5 illustrate the most significant environmental categories for output flows by Pareto graphics. On the one hand, Scenario 1 identifies fossil depletion (FD), climate change (CC) potential, and terrestrial acidification (TA) as the highest contributors. On the other hand, Scenario 2 shows that the terrestrial acidification has a higher impact value than CC. For the fossil depletion category, the brown coal mining is shown as having the highest contribution. Therefore, the climate change category is affected mainly by the combustion of brown coal and thermal energy production for the power unit operation.

For the comparison of both scenarios the following graphics (Figures 6-9) represent differences in the significant (CC, TA, PMF, and POF) environmental categories. The graphs show lower impacts in each category for Scenario 2. The most significant difference is seen in CC where the values for Scenario 2 are almost two-thirds lower than those in Scenario 1. 


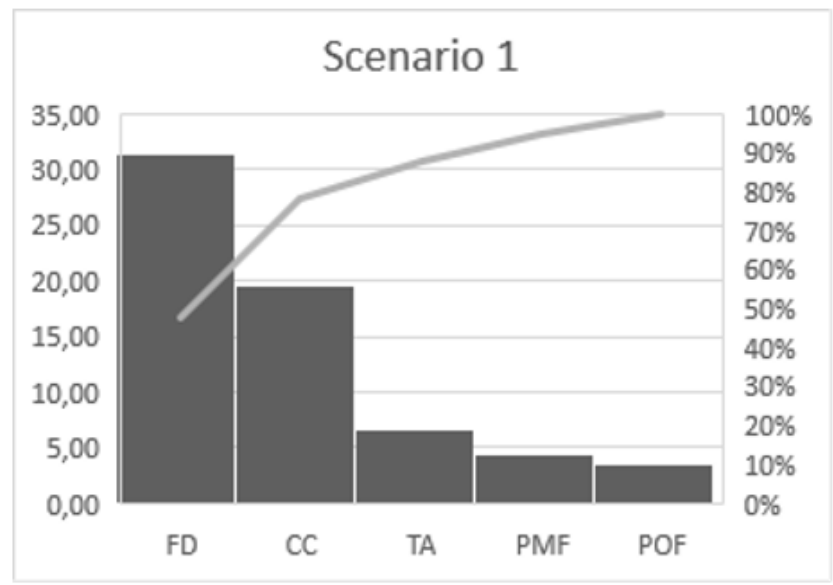

Figure 4. Pareto graph for scenario 1.

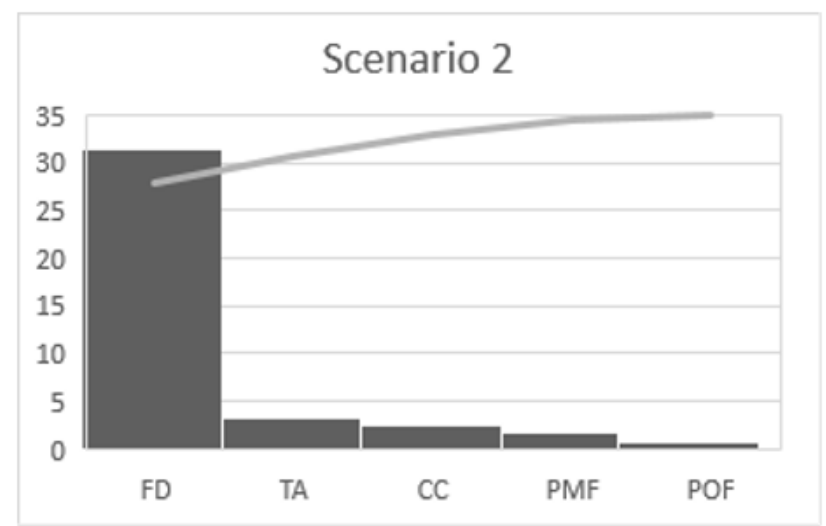

Figure 5. Pareto graph for scenario 2.

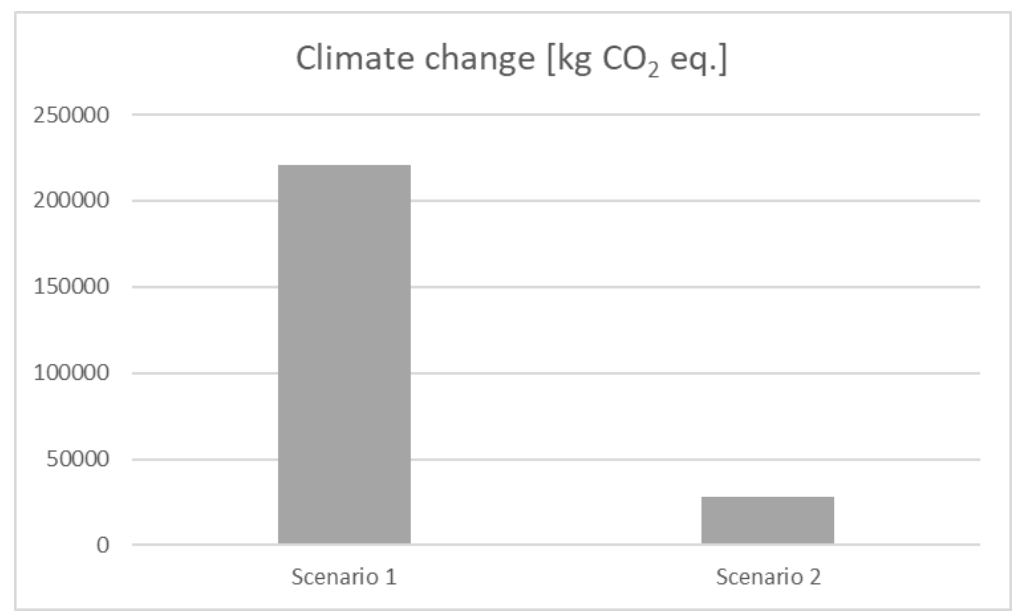

Figure 6. Comparison of scenarios-climate change. 


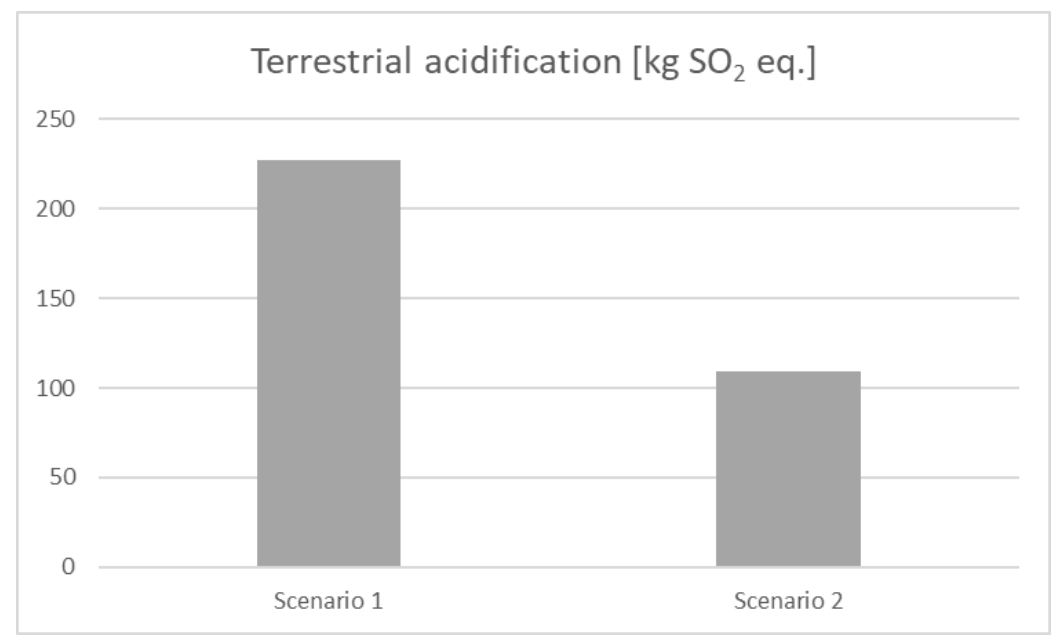

Figure 7. Comparison of scenarios-terrestrial acidification.

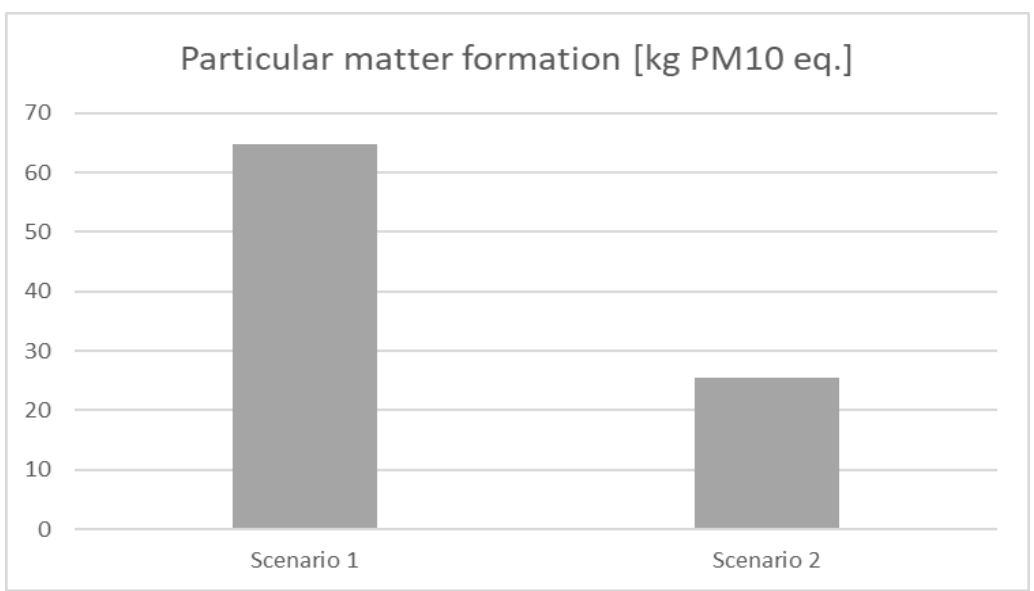

Figure 8. Comparison of scenarios- particular matter formation.

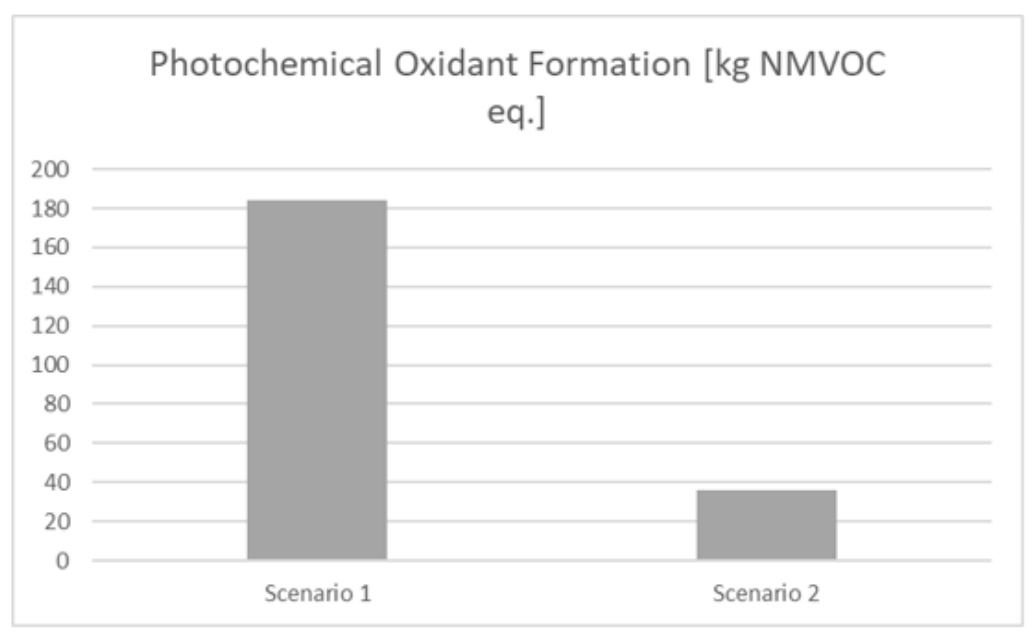

Figure 9. Comparison of scenarios -photochemical oxidant formation.

For Scenario 2, Table 7 shows that the category of fossil depletion is affected mainly by brown coal production and mining. Moreover, terrestrial acidification potential is mainly affected by the $\mathrm{CO}_{2}$ adsorption process. Brown coal combustion and, consequently, production of thermal energy for the adsorption process are also contributors to the acidification potential. Transport has a minor role for both scenarios 
Table 7. Causes of significant environmental impacts in Scenario 2.

\begin{tabular}{|c|c|c|c|c|}
\hline Scenario 2 & Brown Coal Mining & Transport & $\begin{array}{c}\mathrm{CO}_{2} \text { Adsorption } \\
\text { Process }\end{array}$ & $\begin{array}{l}\text { Thermal Energy for } \\
\text { Adsorption Process }\end{array}$ \\
\hline Terrestrial acidification (kg SO 2 eq.) & 15.6 & 3.68 & 82.3 & 7.68 \\
\hline & Brown Coal Mining & Transport & $\mathrm{NaOH}$ Production & Water Consumption \\
\hline Fossil depletion (t oil eq.) & 48.10 & 1.03 & 0.28 & 0.59 \\
\hline
\end{tabular}

Environmental Impact Assessment of Activated Carbon Production

The question of the activated carbon production is crucial for the whole environmental impact analysis. Therefore, further detailed input-output analyses of the process of the activated carbon production is required. Table 8 shows the relative contribution of each category for the activated carbon production for the $\mathrm{CO}_{2}$ adsorption process. The highest contribution refers to the categories of climate change potential and fossil depletion.

Table 8. Environmental assessment of activated carbon production.

\begin{tabular}{ccc}
\hline Environmental Impact Categories & Values in Category Units & Relative Contribution in \% \\
\hline Climate change (kg CO${ }_{2}$ eq.) & 6.98 & 98.46 \\
Fossil depletion (kg oil eq.) & 0.107 & 1.51 \\
Water depletion $\left(\mathrm{m}^{3}\right)$ & 0.002 & 0.03 \\
\hline
\end{tabular}

\subsection{Economical Evaluation of the Payback Period of the Pilot $\mathrm{CO}_{2}$ Capture Unit}

Total capital expenditures according to the required components price are listed in Table 9.

Table 9. Total costs of CCU construction.

\begin{tabular}{cc}
\hline Cost Estimation for Commercial CCU Unit in EURO \\
\hline 4x reactor & 40,000 \\
Fittings & 24,000 \\
Measure appliances & 14,000 \\
$\mathrm{CO}_{2}$ tank (pressurized) & 20,000 \\
Electro + regulations & 12,000 \\
$\mathrm{CO}_{2}$ compression & 6000 \\
Ventilators & 4000 \\
Project & 24,000 \\
Cooling & 8000 \\
Heating (steam transport) & 6000 \\
Others + non predictable & 32,000 \\
Construction & 40,000 \\
\hline Capital expenditure & 434,000 \\
New technology x1,7 & 737,800 \\
\hline
\end{tabular}

Results in Table 10 for the economic feasibility and payback time period were calculated according to Formulas (1) and (2).

Table 10. Payback period (simple, not discounted) for CCU.

\begin{tabular}{ccc}
\hline Expenditures & 737,800 & EUR \\
\hline Operational costs & 36,890 & EUR \\
Captured $\mathrm{CO}_{2}$ & 1200 & $\mathrm{t}$ \\
Cost of $\mathrm{CO}_{2}$ allowance & 25 & $\mathrm{EUR} / \mathrm{t}$ \\
Market price of $\mathrm{CO}_{2}$ produced & 120 & $\mathrm{EUR} / \mathrm{t}$ \\
Income & 174,000 & EUR \\
\hline Payback period & 5.38 & years \\
\hline
\end{tabular}




\section{Discussion}

According to the characterization values in Table 6, the most obvious difference between the two scenarios is the climate change category (Figure 6). This result corresponds to the decrease of $\mathrm{CO}_{2}$ levels by the adsorption process (in Scenario 2), modelled at $75 \% \mathrm{CO}_{2}$ capture from flue gases. The gains in terrestrial acidification potential in Scenario 1 have higher values ( $227 \mathrm{~kg} \mathrm{SO}_{2}$ eq.), which are mainly influenced by $\mathrm{SO}_{2}$ emissions $(119 \mathrm{~kg})$ released into the air after the flue gas treatment. In Scenario 2, this amount of $\mathrm{SO}_{2}$ in flue gases is the input into the adsorption process, thus, the values for the acidification category are lower. In addition, Scenario 1 refers to the higher values in the PMF and POF categories. These categories are influenced by fuel combustion emissions.

Studies by Kantová [25] and Vassilev [26] showed that ash from the brown coal combustion consisted of a high volume of particulate matter (93.08\% from brown coal) which was volatile and persistent in the atmosphere. Therefore, brown coal combustion and the quality of brown coal are significant factors that influence the level of potential environmental harm. According to Kantová, the key parameters for controlled emissions in the process of combustion are low ash content, low moisture levels, and a constant size of volatile particles. In the context of the Czech integrated register of pollutants and emissions restrictions [27], there are no further chemical descriptions of particulate matter (PM), and thus it is complicated to get parameters of produced PMs that directly affect the environmental category of particulate matter formation. Therefore, the chemical analysis of PM produced from Czech brown coal would be an interesting subject for further research.

The Pareto analysis was chosen to distinguish which processes have the greatest impact, particularly for output flows (emissions) in both scenarios which are harder to decide upon. The input flows, which consider the change of the land and resource depletion, show the highest contribution of fossil depletion potential in both scenarios. In both cases, fossil depletion is related to the processes of brown coal mining and production which require $214 \mathrm{t} / \mathrm{h}$ of primary brown coal for the actual operation of the studied power unit. However, the result values for fossil depletion in Scenario 1 does not show any significant difference as compared with Scenario 2, although there is a slightly higher demand for raw material extraction, such as hard coal for activated carbon production. This demand refers to a need for fresh carbon, in the amount of $23 \mathrm{~kg} / \mathrm{h}$, which in the evaluation of the whole life cycle means only a small resource demand. The Pareto analysis for output flows (Figures 4 and 5) considers fossil depletion, climate change, and terrestrial acidification as the most significant contributors to the overall environmental impacts. The only difference lays in the degree of priority for each scenario. For both scenarios, fossil depletion has equal significance, as the values of characterization are the same. In Scenario 1, the impact contribution in second place is climate change and, in Scenario 2 it is terrestrial acidification. Climate change in Scenario 1 is mainly caused by the combustion process of the coal and the production of thermal energy for the power unit. For Scenario 2, Table 7 shows that the processes influencing the category of terrestrial acidification are brown coal mining and $\mathrm{SO}_{2}$ emissions (released into the air after the adsorption process in the amount of $82.3 \mathrm{~kg} \mathrm{SO}_{2}$ eq). The impact of transportation, in both scenarios, is insignificant.

It is also important to mention the category of water consumption. In the relative contribution to environmental impacts, this category does not show any significance. However, in the characterization phase, the consumption of $6400 \mathrm{~m}^{3}$ of water shows that the energy industry plays a role in water management. This is a reminder that the process must also aim to mitigate excessive water consumption, especially in times of global warming and drought danger.

The next step was to assess the production of the activated carbon. The literature review for the LCA of the activated carbon adsorption process showed that environmental studies have focused on the type of activated carbon production. The case study is considering the production of activated carbon from hard coal as a primary source. Therefore, resource depletion, as a direct connection to the category of fossil depletion potential, is affected by hard coal mining. Tar, as an input flow for the activated carbon production, also contributes to resource depletion. On the site of emissions, $\mathrm{CO}_{2}$ emissions from the combustion of natural gas (1133 MJ for activation and carbonization of $7.6 \mathrm{t}$ 
of activated carbon) cause major environmental consequences. Moreover, among all environmental impact categories, climate change has the highest relative contribution (almost 99\%). The impact relates to the combustion of natural gas (Table 8).

The results clearly demonstrate that the power unit with the connection of adsorption process leads to decreased environmental impacts, specifically in the categories of climate change, terrestrial acidification, particulate matter formation, and photochemical oxidant formation. The problem is seen in a primary source, i.e., coal extraction, which, in both scenarios, shows relatively high and equal values. The Czech national energy mix is based on brown coal power plants, and therefore the raw materials extraction and resource depletion creates a significant environmental burden. The extraction of hard coal for activated carbon production also contributes to this fact. The case study counts with just an input of $23 \mathrm{~kg}$ fresh activated carbon, but the basic batch of hard coal is rather bigger and counts with $7.6 \mathrm{t}$, which is an additional amount of raw materials extracted from the ground. The production of the activated carbon could be optimized using different resources such as biomass, which could contribute to reduced consumption of the fossil source.

Finally, the economical consideration (Tables 9 and 10) of the newly built CCU shows a payback period of almost six years (relatively fast for such a small CCU). It must be considered that the market price for a ton of $\mathrm{CO}_{2}$ could be lower, due to lower purity of the $\mathrm{CO}_{2}$ product. If the market price was one-third lower (40 Euro), incomes would change to 78,000 Euros and the payback period would increase to almost 18 years. We conclude that, even if the process of $\mathrm{CO}_{2}$ capture was highly effective, the purity of the final product has a significant role in the economy of the whole process. To make the project feasible, there is a technical requirement to solve the purification process of $\mathrm{CO}_{2}$, leading to an increase of total capital expenditures and of the payback period. Moreover, purified $\mathrm{CO}_{2}$ as a final product could be more attractive for sectors such as agriculture or the food processing industry, and therefore contribute to the national circular economy.

\section{Conclusions}

Carbon dioxide capture by activated carbon adsorption seems to be a promising technology from an environmental perspective. The LCA assessment highlights the main environmental impacts that can arise during the life cycle of the technology.

The robust LCA analyses which included characterization, normalization, and Pareto analyses with input-output analyses are approaches that create a precise model to reflect specific conditions of the technology. The LCA helps to identify the key processes that can be improved with respect to their environmental performance. In addition, the economic calculation completes the sustainability assessment of the newly built technology and gives the perspective of the final product $\left(\mathrm{CO}_{2}\right)$ utilization. It must be stressed that the designed emissions of the capture method are site specific and reflect the local conditions, for example, the type of power plant, fuel type, natural sources (for capture media production), etc. The presented adsorption method was designed for the purpose of $\mathrm{CO}_{2}$ capture from subcritical, coal-fired power plants in the Czech Republic. The sum of the environmental impacts with carbon capture is generally lower than the power unit itself. Nevertheless, this study shows that the Czech energy mix (in both scenarios) leads to high levels of $\mathrm{CO}_{2}, \mathrm{SO}_{2}$ emissions, and solid particulates. As the Czech national energy mix is primarily from brown coal, the depletion of fossils by a primary energy source still remains the main environmental problem, but monitoring of the coal quality, as well as testing the chemical composition of particulate matter, could contribute towards lower potential environmental impacts.

Nevertheless, further research that focuses on various sources (as biomass) for activated carbon production should be considered. Moreover, $\mathrm{CCU}$ could become part of the Czech circular economy, if the purification processes and measures of the $\mathrm{CO}_{2}$ product are wisely chosen and adapted.

Worldwide pressure for low carbon economy transition is forcing the national energy systems to find viable solutions to mitigate the levels of greenhouse gases (GHG). The Czech Republic is slowly shifting towards increased integration of renewable energy systems. However, the coal industry is still 
the prevailing sector, where a sudden shift could be drastic for the national economy and coverage of the power demand. Therefore, the current systems with optimized CCU could be the solution that would help to overcome the transition process. The implementation of all available tools and knowledge to reach this goal is required and would assist choosing and creation of a reasonable and wise strategy for the sustainable development of the country.

Author Contributions: Conceptualization, K.Z. and A.C.; methodology, K.Z. and V.K.; formal analysis, K.Z.; resources, K.Z.; data curation, K.Z. and J.Š.; writing—original draft preparation, K.Z.; writing—review and editing, K.Z.; supervision, V.K. and A.C.; All authors have read and agreed to the published version of the manuscript.

Funding: This research received no external funding.

Acknowledgments: This work was supported by the Technology Agency of the Czech Republic, project number TH03020169 and project number TA02020205 and by institutional support from the University of Chemistry and Technology Prague.

Conflicts of Interest: The authors declare no conflict of interest.

\section{References}

1. European Association for Coal and Lignite. Eurocoal Statistics, Coal in Europe 2017. Available online: www.eurocoal.eu (accessed on 9 February 2019).

2. Czech Statistical Office. Czech Republic in International Comparison-(Selected Indicators)-2017. Available online: www.czso.cz (accessed on 2 February 2019).

3. Grant, T.; Anderson, C.; Hooper, B. Comparative Life Cycle Assessment of Potassium Carbonate and Monoethanolamine Solvents for $\mathrm{CO}_{2}$ Capture from Post Combustion Flue Gases. Int. J. Greenh. Gas Control 2014, 28, 35-44. [CrossRef]

4. Manuilova, A.; Koiwanit, J.; Piewkhaow, L.; Wilson, M.; Chan, C.W.; Tontiwachwuthikul, P. Life Cycle Assessment of Post-Combustion $\mathrm{CO}_{2}$ Capture and $\mathrm{CO}_{2}$-Enhanced Oil Recovery Based on the Boundary Dam Integrated Carbon Capture and Storage Demonstration Project in Saskatchewan. Energy Procedia 2014, 63, 7398-7407. [CrossRef]

5. Koornneef, J.; van Keulen, T.; Faaij, A.; Turkenburg, W. Life Cycle Assessment of a Pulverized Coal Power Plant with Post-Combustion Capture, Transport and Storage of $\mathrm{CO}_{2}$. Int. J. Greenh. Gas Control 2008, 2, 448-467. [CrossRef]

6. Petrakopoulou, F.; Tsatsaronis, G. Can Carbon Dioxide Capture and Storage from Power Plants Reduce the Environmental Impact of Electricity Generation? Energy Fuels 2014, 28, 5327-5338. [CrossRef]

7. Odeh, N.A.; Cockerill, T.T. Life Cycle GHG Assessment of Fossil Fuel Power Plants with Carbon Capture and Storage. Energy Policy 2008, 36, 367-380. [CrossRef]

8. Singh, B.; Strømman, A.H.; Hertwich, E.G. Scenarios for the Environmental Impact of Fossil Fuel Power: Co-Benefits and Trade-Offs of Carbon Capture and Storage. Energy 2012, 45, 762-770. [CrossRef]

9. Clarens, F.; Espí, J.J.; Giraldi, M.R.; Rovira, M.; Vega, L.F. Life Cycle Assessment of CaO Looping versus Amine-Based Absorption for Capturing $\mathrm{CO}_{2}$ in a Subcritical Coal Power Plant. Int. J. Greenh. Gas Control 2016, 46, 18-27. [CrossRef]

10. Hjaila, K.; Baccar, R.; Sarrà, M.; Gasol, C.M.; Blánquez, P. Environmental Impact Associated with Activated Carbon Preparation from Olive-Waste Cake via Life Cycle Assessment. J. Environ. Manag. 2013, 130, 242-247. [CrossRef] [PubMed]

11. Arena, N.; Lee, J.; Clift, R. Life Cycle Assessment of Activated Carbon Production from Coconut Shells. J. Clean. Prod. 2016, 125, 68-77. [CrossRef]

12. Štefanica, J.; Smutná, J.; Kočí, V.; Macháč, P.; Pilař, L. Environmental Gains and Impacts of a CCS Technology-Case Study of Post-Combustion $\mathrm{CO}_{2}$ Separation by Ammonia Absorption. Energy Procedia 2016, 86, 215-218. [CrossRef]

13. Zakuciová, K.; Lapao Rocha, J.; Koci, V. Life Cycle Assessment Overview of Carbon Capture and Storage Technologies. Annu. Int. Conf. Sustain. Energy Environ. Sci. 2016, 84-90. [CrossRef]

14. Pilar, L.; Slouka, P.; Vlček, Z. Technical Report of Project TA02020205; ÚJV Řež, a.s., Řež: Husinec, Czech Republic, 2015. 
15. International Organization for Standardisation. IS/ISO 14044 (2006): Environmental Management-Life Cycle Assessment-Requirements and Guidelines; Bureau of Indian Standarts: New Delhi, India, 2006.

16. Hauschild, M.Z.; Rosenbaum, R.K.; Olsen, S.I. Life Cycle Assessment, Theory and Practice; Springer International Publishing AG: Montpellier, France, 2018. [CrossRef]

17. Goedkoop, M.; Heijungs, R.; Huijbregts, M.; De Schryver, A.; Struijs, J.; Van Zelm, R. ReCiPe 2008 First Edition (Version 1.08) Report I: Characterisation; Ministry of foreign Affairs: Rijnstraat, Netherlands, 2013.

18. Jolliet, O.; Margni, M.; Charles, R.; Humbert, S.; Payet, J.; Rebitzer, G.; Rosenbaum, R. Presemmg a New Meth6d IMPACT 2002+: A New Life Cycle Impact Assessment Methodology. Int. J. Life Cycle Assess 2003, 8, 324-330. [CrossRef]

19. Benini, L.; Mancini, L.; Sala, S.; Schau, E.; Manfredi, S.; Pant, R. Normalisation Method and Data for Environmental Footprints; Office of the European Union: Luxembourg, 2014; Volume 113. [CrossRef]

20. Carvalho, A.; Mimoso, A.F.; Mendes, A.N.; Matos, H.A. From a Literature Review to a Framework for Environmental Process Impact Assessment Index. J. Clean. Prod. 2014, 64, 36-62. [CrossRef]

21. Shen, L.; Patel, M.K. Lca Single Score Analysis of Man-Made Cellulose Fibres. Lenzing. Ber. 2010, 88, 7.

22. CEZ Group. Power Plant Prunerov. Available online: www.cez.cz (accessed on 9 February 2018).

23. Tzimas, E.; Georgakaki, A.; Peteves, S. Reducing $\mathrm{CO}_{2}$ Emissions from the European Power Generation Sector-Scenarios to 2050. Energy Procedia 2009, 1, 4007-4013. [CrossRef]

24. Vávrová, J.; Štefanica, J.; Hájek, P.; Smejkalová, J. Technical Report of Project TA02020205; ÚJV Řež, a.s., Řež: Husinec, Czech Republic, 2013.

25. Kantová, N.; Holubčík, M.; Jandačka, J.; Čaja, A. Comparison of Particulate Matters Properties from Combustion of Wood Biomass and Brown Coal. Procedia Eng. 2017, 192, 416-420. [CrossRef]

26. Vassilev, S.V.; Vassileva, C.G.; Vassilev, V.S. Advantages and Disadvantages of Composition and Properties of Biomass in Comparison with Coal: An Overview. Fuel 2015, 158, 330-350. [CrossRef]

27. Ministerstvo Zivotniho Prostredi České Republiky. Integrovany Registr Znecistovani. Available online: www.irz.cz (accessed on 8 February 2018).

(C) 2020 by the authors. Licensee MDPI, Basel, Switzerland. This article is an open access article distributed under the terms and conditions of the Creative Commons Attribution (CC BY) license (http://creativecommons.org/licenses/by/4.0/). 